\title{
Determinants of foreign direct investment in advanced business services ${ }^{\star}$
}

\begin{abstract}
ARTUR KLIMEK* (1)
Wroclaw University of Economics and Business, ul. Komandorska 118/120, 53-345, Wrocław, Poland

Received: April 28, 2018 • Revised manuscript received: August 28, 2018 • Accepted: June 19, 2019

(ㄷ) 2020 Akadémiai Kiadó, Budapest

ABSTRACT

This paper is aimed at investigating determinants of recent flows of foreign direct investment (FDI) into advanced business services (ABS) in the European Union with the distinction between "old" (till 2004) and "new" member states (after 2004 extension). Special attention is put on the Visegrád countries. The factors affecting location decisions of multinational corporations were analysed at the national and regional level. The latter approach proved to be very effective due to the fact that foreign companies operating in ABS are highly unequally distributed across economies. Indeed, there are only few regions in economies attracting bulk of the operations in ABS.

The research method applied in the paper is negative binomial regression, which measures the probability of occurrence of an ABS foreign firm in an economy or a region taking into consideration its characteristics. This research combines macroeconomic, regional and firm-level data. The explanatory variables are divided into two groups: demand and supply. The main conclusion is the high significance of the supply factors. In other words, foreign companies focus on locations offering large number of skilled workers at reasonable prices. The key recommendation for governments interested in attracting ABS type of investment is to focus on the quality of human capital.
\end{abstract}

\section{KEYWORDS}

foreign direct investment, advanced business services, regions, european union, visegrád countries

\section{JEL CLASSIFICATION INDICES}

F21, F23

\footnotetext{
*E-mail: artur.klimek@ue.wroc.pl

${ }^{*}$ An earlier version of the paper was presented in the European Trade Study Group Conference in Helsinki, September 8-10, 2016.
} 


\section{INTRODUCTION}

Motives of foreign direct investment (FDI) may be unique for each investing firm. However, from the policy point of view, a general pattern of determinants is crucial. It allows governments to design an efficient investment support strategy and to address incentives properly. The main goal of such policies should be attracting high quality FDI to the designated locations. Thus, the analysis of determinants of FDI should take into consideration the industry and spatial characteristics. It is therefore not surprising, that a representative of an investment promotion agency said in a conversation that investors would come to an attractive region even without any incentives, but the peripheral locations need a special attention.

An important paradigm of national investment strategies is to attract foreign enterprises into services. The fragmentation of business activities, that first took place in manufacturing, was essential in introducing less developed countries into the global economy. Nowadays, the focus shifts towards business services (BS), which constitute a distinctive group within the broad sector of services. Thanks to the organisational and technological advances, BS have become internationally tradable and attracted vast amounts of foreign investment. These all made BS a very important element of international economic analysis.

Especially the focus is on the knowledge-intensive business services (KIBS) or advanced business services (ABS). They are defined as relying heavily on professional knowledge (Miles et al. 1995). Examples of such services are: IT support, management consultancy and technical engineering (den Hertog 2000). KIBS firms are also more innovative than manufacturing ones that results in the higher average innovation intensity (Kam - Singh 2004). The ABS are prone to FDI, what is confirmed by the recent focus of multinational corporations (MNCs) on establishing subsidiaries providing such activities in various locations. Therefore, these services are also referred to as global business services (Wirzt et al. 2015).

This paper is aimed at investigating recent flows of FDI into ABS in the European Union (EU) with the distinction between "old" (till 2004) and "new" member states (2004 extension). Moreover, special attention is put on the Visegrád countries (Czech Republic, Hungary, Poland and Slovakia: V4). Such an approach is stems from the rising importance of such operations in so called "new Europe". The selection of these economies is justified by a significant increase in the number and value of investment projects in the analysed sector in the last decade. The number of new investment projects in services by foreign MNCs is high and sufficient time has elapsed to assess the effects of the projects already completed. Additional measure of the significance of business services sector is the level of employment, which reached 260,000 jobs in Poland (ABSL in Poland 2018), mostly in enterprises with foreign capital. Approximate numbers of jobs in other countries in the region are as follows: Hungary - 40,000 (HIPA 2017); Czech Republic - 75,000 (ABSL in the Czech Republic 2017); and Slovakia - 30,000 (SARIO 2017). According to some estimates in the coming years, this level may rise to about 1 million throughout the V4 economies.

The rise of offshoring of white-collar workers in the V4 economies attracted attention of economists. The role of ABS in Hungary's economy was analysed by Sass (2011). Klimek (2018) focused on the agglomeration economies as an important factor in the decision of locating FDI in ABS in Poland. Selected factors of attractiveness of Poland as a host economy for ABS were presented by Micek (2015). He also tried to forecast the impact of ABS firms for the economic development, however his negative expectations (closure of ABS firms or being locked to less knowledge-intensive services) have not materialised yet. 
This paper aims at enriching literature regarding FDI in several ways. First, the novelty of the paper lies in using a unique dataset that contains observations specifically selected as belonging to the ABS. The dataset is constructed using firm-level data what allowed for elimination of observations not meeting the criteria of activities described as ABS. The next novelty lays in the attitude towards FDI. The firm-level data allowed for selecting the companies created as a result of FDI. Such an approach helped avoiding transactions with no real operations or only using the round tripping. This is the case especially in services, which are frequently used in tax optimisation strategies. Third, the factors influencing decision about FDI in ABS were divided into two groups: supply and demand, and the analysis was conducted accordingly.

The research method applied in the paper is the negative binomial regression, which is the extension of the Poisson model. The research approach is designed for the outcome data of the count nature. The outcome variable is the number of foreign firms operating in the selected services, which is affected by the set of explanatory variables.

The paper is organised as follows. After this introduction, Section 2 delivers a review of previous contributions in the field of determinants of ABS; Section 3 contains data description; Section 4 shows the outline of an econometric strategy; Section 5 contains the results of the analysis; and Section 6 delivers concluding remarks.

\section{PREVIOUS THEORETICAL AND EMPIRICAL CONTRIBUTIONS ON ADVANCED BUSINESS SERVICES (ABS)}

Previous contributions focused greatly on BS in the broad meaning of this notion, including for example, trade and transportation. Such services are very different from ABS, which are based on knowledge and high skills. ABS are increasingly important for the competitiveness of firms and in effect also the entire economies. ABS may be considered from the expansion and consolidation point of view. When it comes to the expansion, ABS such as research and development or consultation create unique knowledge giving the edge to companies. When it comes to the consolidation, ABS help to reduce costs and increase efficiency of processes. It is also important to note that large firms (notably MNCs) have more capabilities to introduce organisational improvements.

More specifically, theoretical contributions dealing with FDI in BS are rather scarce and they are based on manufacturing activities. Moreover, the approach generally focuses on services in a broader meaning. As a result, there are no explicit and widely accepted theoretical economic models explaining FDI in ABS. Anyway, a very useful approach to BS and international flows was provided by Markusen - Strand (2009). Their starting point was to conceptualise barriers to international flows of services and to establish commercial presence using FDI. They argued that due to the different nature of barriers to provision of services than those pertaining to goods, a new approach to modelling services, especially those of business type, in the global economy is required. Such a conclusion is also relevant from the point of view of determinants of a location decision. According to Markusen - Strand (2009) differences in relative factor endowments between countries play a minor role in concentration of services in certain locations. However, they argued that there is concentration of service operations at the level of cities. I think that this is a further argument for the conclusion that FDI projects in ABS are not equally distributed among the host countries. This confirms the need of including regions or cities in the analysis of 


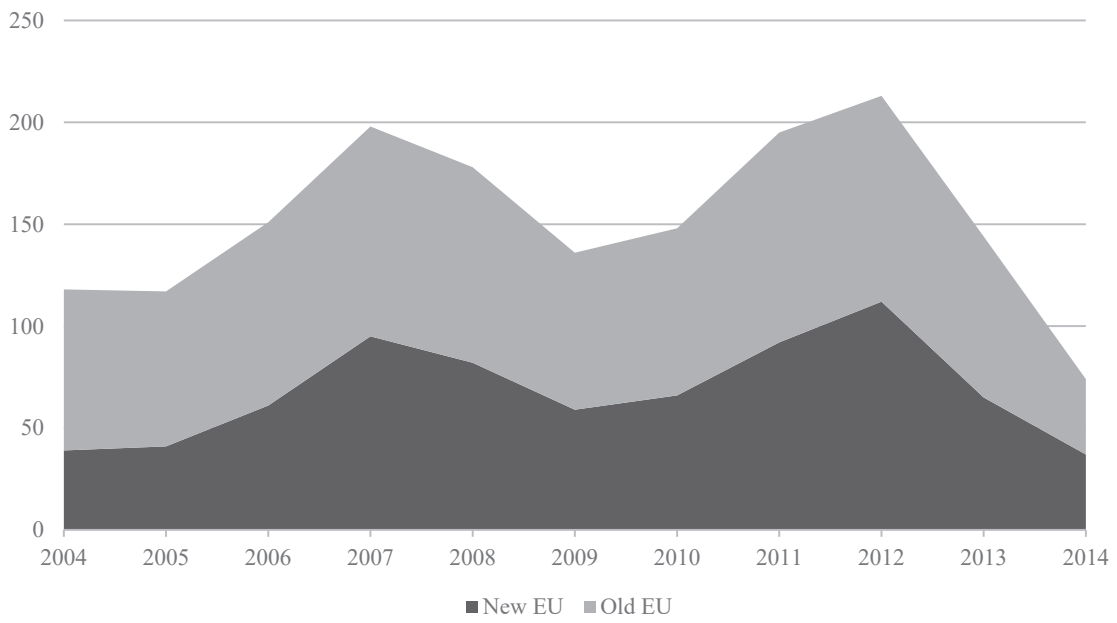

Fig. 1. Number of foreign companies established in advanced business services Source: Own elaboration based on Amadeus data.

FDI localisation. The advantage of the Markusen - Strand (2009) model is also explaining the effects of service activities for the production factors' markets in a host economy. Nevertheless, their approach has some shortcomings as the model fails to comprehend advanced organisational strategies of MNCs.

There is also little empirical evidence regarding the determinants of location choices of FDI in ABS. Mostly due to better availability of data, the empirical evidence regarding the factors influencing inflow of FDI into manufacturing is much richer e.g. Head et al. (1999) or Amiti Smarzynska Javorcik (2005). An additional essential element of investment in manufacturing were agglomeration economies. Especially reducing transportation costs leads to more agglomeration in the industries with vertical links (Venables 1996). Agglomeration effects are even more evident in the ABS sector (see comment to Fig. 2).

The existing evidence most frequently subordinates FDI in business services to a prior manufacturing investment. Nefussi - Schwellnus (2010) applied the analytical framework designed to explain FDI in manufacturing sector to study FDI in services. They concluded that estimated results for services and manufacturing are similar due to the complementarities between two sectors. However, they focused on the broad category of BS, not only on those representing high level of knowledge-intensity. Additionally, the research approach frequently applied could not distinguish between different types of services (Ramasamy - Yeung 2007). They argued that in order to develop FDI in services an economy should focus on manufacturing FDI first.

Building links between investments in services and prior investments in manufacturing is the main approach in the empirical literature. The role of services has been diminished only to support activities of more important production activities. Thus, business services have not been treated as autonomous operations. Moreover, the role of services as intermediary to other 


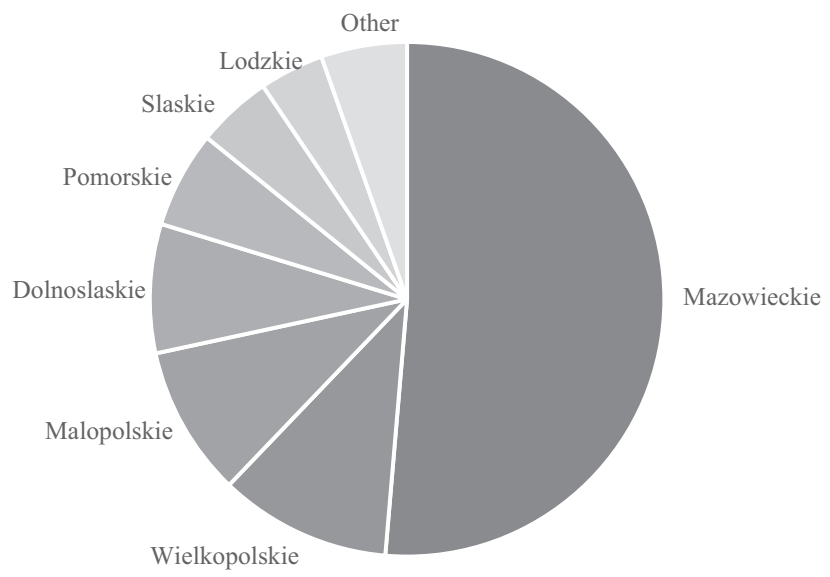

Fig. 2. Main locations of foreign-owned ABS in Poland 2004-2014 (\%) Source: Own elaboration based on Amadeus data.

business services has been neglected. In fact, many of the IT and accounting operations are delivered to financial or transportation firms. Such an approach has also not taken into consideration that services do not have to be provided in the same location as manufacturing due to the communication technologies. This is also against the theoretical framework of MNC, which assumes that the knowledge-intensive services can be supplied to additional production facilities at low cost and they can be separated geographically from the production (Carr et al. 1998).

One cannot downplay the evidence on FDI manufacturing in explaining FDI services, but it is necessary to indicate specific features of services, especially those of knowledge-intensive type. I argue that due to the high level of tradability and codification of knowledge in ABS, they do not need to be placed close to the manufacturing operations. This is in line with the empirical characteristics of offshoring of white-collar services presented by Markusen (2005). Moreover, some assumptions regarding location choice of services might lead to different effects of distance than it was the case for manufacturing (Navaretti - Vanables 2004). This in turn requires a completely different approach to the role of transportation and trade barriers.

An additional strand in the empirical analysis focuses on employing data at the regional level instead of the national one. The European regions were analysed by Castellani et al. (2013) or Pylak et al., 2020. They focused on linkages between investment in manufacturing and business services. The analysis included the period of 2003-2008, therefore it did not contain the period of a large wave of investment projects to the new member states. However, I argue that investment in services is attracted to the same locations as manufacturing and this is the result of high attractiveness for the investors. Such regions are more attractive and offer better supply of production factors than other parts of economies. The significant variation in the role of factors attracting FDI in services at the regional level was also confirmed in the case of e.g. China (Yin et al. 2014). However, the regional differences are also crucial in smaller economies. 
A separate strand in the literature concerns determinants of FDI in the emerging Europe. Regional study of the Croatian regions confirmed the positive role of infrastructure and human capital (Kersan-Škabić - Tijanić 2014). Determinants of FDI vary when it comes to sectors. According to Walsh - Yu (2010), investments in the primary sector were not affected by the level of development, macroeconomic policies and quality of institutions. These factors were very important for manufacturing and services sectors. Still there are significant differences between the secondary and tertiary sectors when it comes to the importance of the particular factors. Services are attracted to dynamically developing and open economies.

All in all, this paper focuses on FDI in ABS, which are assumed to be attracted by the factors distinguishing from manufacturing or consumer services. Moreover, the analysis at the regional level is considered to have strong advantages in explaining determinants of investment in ABS, and therefore, will be used in this paper as the principal approach.

\section{DATA AND VARIABLES}

Data on the number of investment projects in ABS were elaborated using Amadeus database. This is a large database containing information about 21 million European private and public companies (Bureau van Dijk 2018). ${ }^{1}$

In order to avoid drawbacks of pure FDI data (especially that on higher level of aggregation), which just provide information about the capital flows or stocks, I focus on the outcome of foreign investment (by companies where foreign ownership is above 50\%). Actually, in most cases the share of foreign ownership equals $100 \%$.

The firms analysed in the paper are results of greenfield investment which were established by the foreign owners in the period of 2004-2014. The motivation was analysing operations after enlarging the EU, and thus, increasing possibility of investment in services. Moreover, this was also the period of an unprecedented growth of business services in the EU, especially in the new member states (Fig. 1).

Five NACE Rev. 2 activities were selected for the analysis:

6209 - Other information technology and computer service activities,

6910 - Legal activities,

6920 - Accounting, bookkeeping and auditing activities, tax consultancy,

721 - Research and experimental development on natural sciences and engineering,

722 - Research and experimental development on social sciences and humanities.

According to my best knowledge, such a composition of the population gives the most precise image of the entities operating in the ABS. In this study, ABS sector includes: business process outsourcing, shared service centres, information technology outsourcing and research and development centres.

\footnotetext{
${ }^{1}$ It provides both basic financial information (from balance sheets, profit and loss statements, cash flow reports) and details of the ownership. There is also detailed information about the linkages between companies, what helps to analyse their international structures. Because of these qualities, Amadeus database has been frequently used by researchers as a source of the comprehensive firm-level data.
} 
Such an approach helped to list the companies that were purely engaged in ABS. If the number of activities were expanded some holding companies or manufacturing firms organised under an umbrella of a service company would have been included, what might devastate the results of the study. There are doubts that many earlier studies included broader categories pertaining not only to service firms, and not only to FDI in ABS. The list of companies for this study was elaborated using financial details of their operations. In doing so, I analysed the information from balance sheets and profit and loss statements.

The data revealed some worrisome facts. E.g. all Irish firms had to be removed due to a strong evidence that some of them were not established for services delivery but for the purpose of tax optimisation. The largest company in Ireland reported revenue of over 12 billion euros employing just 54 people. In many cases the value of revenue was disproportionate to the size of operations. I can associate it with the tax optimisation strategy referred to as Double Irish. ${ }^{2}$ For similar reasons, firms from Cyprus and Malta were also removed. Additional cleaning was of technical nature: British and Greek firms were removed due to lack of NUTS 2 designation.

There were also additional selection criteria applied of having at least 1,000 EUR of turnover reported for the year 2014. All the limitations helped to exclude records with no operations or operations not belonging to services, but rather manufacturing. The size of the original sample equalled 2,201 firms in the EU being created in the assigned period. After the cleaning operations the final size of the sample was 1,672 records.

Eurostat provided data on the regional level - NUTS 2. ${ }^{3}$ There were 154 regions included in the analysis. The source of data on the macro-level was OECD Stat. The final list of countries encompassed $18 \mathrm{EU}$ member states, including 6 countries that joined in the year 2004 .

The regional approach to the analysis of FDI inflows in ABS is crucial (Fig. 2). The main fact is an unequal distribution of foreign-owned companies across the countries and significant agglomeration effects. In the case of Poland, out of 16 NUTS 2 regions, only 12 received any foreign investment in $\mathrm{ABS}$, and only 9 regions received more than 1 . An extreme situation is observed in the case of the Mazowieckie (Masovian) region, which took over $50 \%$ of all projects. This is the capital region of the country. There are 4 regions that received a large portion of FDI projects $(80 \%)$ in Poland, however in the case of e.g. Hungary only one central region took around $80 \%$ of all projects. The presence of foreign-owned firms increases the concentration of economic activities in the selected attractive regions. This is again the case for industrial activities in Hungary being clustered in the capital region and in the regions laying between the capital and the Austrian border (Lengyel - Szakálné Kanyó 2014). Similar patterns were observed in most of the analysed countries.

In the CEE countries the large flow of FDI in ABS occurred only recently. It is important to note that even in the group of the CEE countries there is a big differentiation in the regional distribution of new investments in ABS.

The dependent variable is the number of foreign-controlled companies belonging to a particular NACE group that were established between 2004 and 2014. In the regional-level analysis the dependent variable is the number of companies in particular of NUTS 2 regions. In

\footnotetext{
${ }^{2}$ Double Irish is a tax avoidance strategy using two Irish companies, first one with tax residency in an offshore tax jurisdiction and the second one with tax residency in Ireland.

${ }^{3}$ List of NUTS 2 regions may be provided on the request.
} 
Table 1. Description of independent variables at regional level.

\begin{tabular}{|c|c|}
\hline Variable & Description \\
\hline \multicolumn{2}{|l|}{ Supply factors } \\
\hline Number of students & $\begin{array}{l}\text { Number of students in tertiary education by NUTS } 2 \text { regions. Unit: } \\
\qquad 1,000 \text { students. }\end{array}$ \\
\hline Human capital & $\begin{array}{c}\text { Population aged 30-34 with tertiary educational attainment by NUTS } 2 \\
\text { regions. Unit: } \% \text {. }\end{array}$ \\
\hline Unemployment & Unemployment rate in the group $25+$ by NUTS 2 regions. Unit: $\%$. \\
\hline Salaries & $\begin{array}{c}\text { Compensation of employees divided by employment by NUTS } 2 \\
\text { regions. Unit: } 1,000 \text { euro. }\end{array}$ \\
\hline \multicolumn{2}{|l|}{ Demand factors } \\
\hline Market size & GDP at current market prices by NUTS 2 regions. Unit: million euro. \\
\hline Market attractiveness & $\begin{array}{l}\text { Real growth rate of regional gross value added at basic prices by NUTS } \\
2 \text { regions. Unit: percentage change on previous year. }\end{array}$ \\
\hline
\end{tabular}

Source: Eurostat.

the economy-wide analysis the dependent variable is the number of foreign companies in a particular country.

The explanatory variables are divided into two groups: supply and demand factors. Moreover, I intend to provide robust results, therefore separate specifications for data on regional and macroeconomic level is provided (Tables 1 and 2). Summary statistics of the variables are provided in the Appendix.

Table 2. Description of independent variables at country level

\begin{tabular}{|l|r|}
\hline Variable & Description \\
\hline Supply factors & Share of population living in urban areas. Unit: \%. \\
\hline Urbanization & Tertiary level enrolment rate. Unit: \%. \\
\hline University rate & Total employment in senvice sector. Unit: \%. \\
\hline Employment in services & Annual salary in the economy. Unit: US dollar. \\
\hline Salaries & \multicolumn{2}{|c|}{} \\
\hline Demand factors & GDP at current market prices. Unit: billion US dollar. \\
\hline Market size & Gross national income per capita. Unit: US dollar. \\
\hline Market attractiveness & Trade openness: Unit: \%. \\
\hline Trade openness &
\end{tabular}

Source: OECD. 
The above factors were both rooted in the international economic and international business theory and evidence. According to Li - Guisinger (1992), the inflow of FDI in services is positively related to the market size and openness of the host economy. The empirical results of Falk (2012), who analysed the greenfield FDI projects in KIBS inflow to the EU, confirmed the importance of wage cost, tertiary education, corporate taxes, having a common border and sharing a common language which are all important for investment decisions.

In the regional level, Caughlin et al. (1991) identified labour market conditions, agglomeration economies, and income per capita among factors influencing the location decisions of MNCs in the US. Similar factors of regional attractiveness for foreign investors in China were investigated by Wei et al. (1999).

\section{ECONOMETRIC STRATEGY}

The econometric approach was based on count data (the number of foreign-owned firms in a territorial unit), what stipulated using a form of the Poisson regression. The basic form of the Poisson probability function is given as follows:

$$
\mathrm{P}(n)=\exp (-\lambda) \lambda^{n / n}
$$

where $\lambda$ is the mean and the variance of the distribution and $n$ is a count of the number of times an event occurs. In this case $\lambda$ means a Poisson distribution parameter related to the set of predictor variables $x_{i}$ influencing the number of foreign-owned companies operating in the ABS in a territorial unit $i$ :

$$
\lambda_{i}=\exp \left(\beta x_{i}\right)
$$

Equidispersion can be presented by the following equation:

$$
\mathrm{E}(n)=\operatorname{var}(n)
$$

However, the observed data frequently display overdispersion (Greene 2008). Overdispersion (mean of the outcome variable was much lower than its variance) of data was revealed by summary statistics, therefore an extension to the general Poisson form had to be applied. The problem of overdispersion is solved by a negative binomial regression model (NBRM).

The functional form of the model for cross-section regional data is given as follows:

$$
\ln \lambda_{i}=\alpha+\beta^{\prime} x_{i}+\varepsilon_{i}
$$

where $\alpha$ is the constant term, $\beta^{\prime}$ represents a vector of coefficients on explanatory variables to be estimated, $\varepsilon_{i}$ stands for the error term.

Two specifications of the model were estimated in order to investigate the determinants of FDI in ABS. The predictor variables described the supply (column 1 in Table 3) and demand (column 2 in Table 3) factors in the period of the analysis. The conversion of explanatory variables into the cross-section format was conducted using averaging, while the conversion of the dependent variable was through aggregation. In other words, I want to investigate the influence of average values of explanatory variables on the total number of foreign-owned firms in a region in the period of 2004-2014. 
Table 3. Results of NBRM using regional data

\begin{tabular}{|l|c|c|}
\hline & (1) Supply factors & (2) Demand factors \\
\hline Observations & 120 & 93 \\
\hline Constant & $2.2712(0.4617)$ & $0.3166(0.1330)$ \\
\hline Supply & $0.0052^{* * *}(0.0015)$ & \multirow{2}{*}{} \\
\cline { 1 - 2 } Number of students & $0.0386^{* * *}(0.0136)$ & \multirow{2}{*}{} \\
\cline { 1 - 2 } Human capital & $-0.0692^{* * *}(0.0324)$ & \\
\cline { 1 - 2 } Unemployment & $-0.0656^{* * *}(0.0159)$ & $0.0061^{* * *}(0.0022)$ \\
\cline { 1 - 2 } Salaries & \multicolumn{2}{|c|}{$0.4600^{* * *}(0.0757)$} \\
\cline { 1 - 2 } Demand & &
\end{tabular}

Notes: Standard errors in parentheses; ${ }^{* * *}$ significance at $0.01,{ }^{* *}$ significance at $0.05,{ }^{*}$ significance at 0.1 level.

The panel data analysis included fixed effects, which remove the effects of time-invariant characteristics of economies. The functional form of the model for panel economy-wide data is given as follows:

$$
\ln \lambda_{i}=\alpha+\beta^{\prime} x_{i t}+\mu_{i}+\varepsilon_{i t}
$$

where $\alpha$ is the constant term, $\beta^{\prime}$ represents a vector of coefficients on explanatory variables to be estimated, $\mu_{i}$ represents the country fixed effects, $\varepsilon_{i t}$ stands for the error term.

The panel is of a strongly balanced form (see the Appendix for the number of observations for each variable). The predictor variables described the supply (column 1 in Table 4) and demand (column 2 in Table 4) factors in the period of the analysis.

\section{ESTIMATION RESULTS}

Results of the econometric analysis highlighted the power of the regional determinants of attracting FDI into the modern BS. Moreover, this study revealed strong influence of both supply and demand factors on the number of foreign-owned firms in ABS, what was confirmed by high statistical significance of the coefficients. The supply coefficients had values according to the underlying theory (column 1 in Table 3 ). Hence, ABS are very knowledge-intensive and require vast resources of human capital. According to the results, regions having larger number of university students and larger share of highly educated population attracted larger number of foreign firms.

Not only the quality of production factors, but also their prices matter for the potential foreign investors. It was revealed by the significance of the coefficient for salaries. The higher the 
Table 4. Results of NBRM using panel data at country level

\begin{tabular}{|c|c|c|}
\hline & (1) Supply factors & (2) Demand factors \\
\hline Observations & 161 & 166 \\
\hline Number of groups & 17 & 18 \\
\hline Constant & $2.3735(2.1621)$ & $1.9508(0.4855)$ \\
\hline \multicolumn{3}{|l|}{ Supply } \\
\hline Urbanization & $-0.0181(0.0390)$ & \\
\hline University rate & $0.0137 *(0.0075)$ & \\
\hline Employment in services & $-0.0099(0.0238)$ & \\
\hline Salaries & $0.0001 * *(0.0000)$ & \\
\hline \multicolumn{3}{|l|}{ Demand } \\
\hline GDP & & $-0.0008 * * *(0.0003)$ \\
\hline GNI per capita & & $0.0001 * * *(0.0000)$ \\
\hline Trade openness & & $-0.0183^{* * *}(0.0074)$ \\
\hline
\end{tabular}

Notes: Standard errors in parentheses; ${ }^{* * *}$ significance at $0.01,{ }^{* *}$ significance at $0.05,{ }^{*}$ significance at 0.1 level.

salaries in the region the lower is the number of investors in ABS. Another important element of the analysis was the level of unemployment. Investors were looking for destinations with abundance of human capital. This can be interpreted as a part of global quest for talents. However, both in the old and in the new EU countries the number of available highly qualified workers is limited. There is a strong competition between foreign investors to attract talented staff. Therefore, the period of the first decade after the large expansion of the EU in 2004 was crucial in the development of modern BS in the new member states.

The variables pertaining to the demand at the regional level were also highly important (column 2 in Table 3). It means that investors are attracted towards larger and more prosperous regions. These results can be associated with earlier evidence that size of the market and its growth are important factors because of the links between ABS and other industries. However, the demand factors may be also associated with the supply factors. Thus, the larger and growing regions are attracting more and better skilled employees to all industries.

The econometric evidence on the level of economies was less conclusive. The demand factors proved their importance, however the sign of the coefficient for size of an economy was negative (column 2 in Table 4). The fact is that many smaller economies like Slovakia, Estonia, the Czech Republic and Luxemburg are attracting disproportionally large number of investment projects in ABS. The second macroeconomic factor - GDP per capita - being a rough measure of the level of wealth in the economy - came as expected. Higher level of the measure increases the number of foreign companies in an economy. The fact is also that firms investing in each EU country take advantage of the common market, what may reduce the role of the demand factors in individual member states. 
The last variable belonging to the demand group - openness to trade - had also negative sign. The variable measures the level of trade in services to GDP and can be interpreted as the intensity of trade in services in particular economies. The results indicate that economies less trading in services are attracting more investment projects. There are two explanations of such results. On the one hand, it indicates that investment is directed into economies with less developed services sector, the low intensity of trade means an economy less saturated with services. This seems to be the case, especially when it is linked to the supply factors - firms are looking for destinations with abundance of skilled workers in locations of low service saturation. It is confirmed by the data on the new foreign-owned firms in "new Europe". On the other hand, this can be interpreted as the investment in a country with some restrictions to trade in services, the motive of jumping over trade barriers is also relevant. It is important to note that only the EU economies were studied in this paper, however the business links through FDI in ABS have a global form. Moreover, the ABS are assumed to be highly tradable, therefore MNCs should focus on the locations offering ease of trade.

The supply factors on the macro level were quite mixed (column 1 in Table 4). First, only two out of four coefficients were statistically significant. Level of education proved to be an important factor for the overall number of projects. The second significant coefficient - salaries - was not as expected. According to the study, higher salaries were translated into larger number of projects. Anyway, the value of the coefficient was very low. It can be interpreted that the KIBS investment are directed into economies of higher level of human capital, but at the same time of higher salaries. This is not in line with the first part of the analysis, when lower salaries in regions were increasing the number of companies operating there.

I believe that such a two-level analysis of determinants improves the understanding of investment decisions in ABS. The most important factors both on country and regional level, were those of the supply side: the level of education and abundance of highly qualified workers. The demand factors were quite inconclusive.

This study confirmed the importance of the level of income on the location of ABS units. This is in line with the previous studies for other samples Liu et al., 2011. The result for salaries was partially in line with earlier evidence regarding FDI in Poland. According to Cieślik (2013) the higher wages did not decrease the value of the new investment, but it was the sign of the economic attractiveness of particular regions.

Anyway, according to these studies, the direct cost difference is not a sufficient factor for attracting FDI. What matters is also the quality of institutional environment, which was excluded in this research as the EU tries to create a unique area of similar institutional environment.

\section{CONCLUSIONS}

This paper is devoted to the analysis of determinants of FDI into ABS. The aim was to investigate factors affecting location decisions of MNCs using both economy-wide and regional perspective. The latter proved to be an especially efficient approach. This is due to the fact that foreign companies operating in ABS are very unequally distributed across particular economies. As a result, there are only few regions attracting bulk of the operations in ABS in each economy. The research approach was limited only to the regions that received at least one project in the period of 2004-2014. Owing to such an approach I could focus only on the regions with some potential to attract investment in ABS. 
The main conclusion of the research is the high significance of the supply factors. In other words, foreign companies focus on locations offering large number of skilled workers at a reasonable wage level. The regions of the new Europe have been characterised by a large pool of highly qualified workers with lower salaries in comparison to the old Europe. The old EU companies took advantage of lower production cost and abundance of skills in the new EU member states. MNCs from outside EU were also motivated by the cost factors, but also focus on free movement of services across the EU.

The key recommendation for governments interested in attracting ABS type of investment is to focus on increasing the supply and quality of human capital. This is crucial for development of many economies and can be observed in investment policies aimed at attracting KIBS. The government agencies responsible for assisting foreign investors highlight ABS as the desired and supported activities.

Further steps of the research should focus on even more detailed data. One of the proposals is to include data at the regional NUTS 3 level. Such an approach may be justified by the fact that most of the projects are located not only in several NUTS 2 regions but only in several cities across particular economies. Then additional determinants may be taken into consideration, such as office rent or quality of life that varies within particular cities. Therefore, data on such detailed level may shed some more light on the issue of the determinants. Additionally, the analysis should focus more on the firm-level data in order to take into consideration the characteristics of particular investors. Among the variables to be included in the analysis we can list: size of a firm, financial efficiency of a firm and research and development expenditures. In order to focus on the V4 countries, the econometric strategy should distinguish between firms with ABS units in the highly developed and emerging European economies.

\section{ACKNOWLEDGEMENTS}

The project has been financed by the National Science Centre, Poland according to the decision no. DEC-2015/19/B/HS4/00356.

\section{REFERENCES}

ABSL in the Czech Republic (2017): Business Services Sector in the Czech Republic 2017. Association of Business Service Leaders in the Czech Republic.

ABSL in Poland (2018): Business Service Sector in Poland 2018. Association of Business Service Leaders in Poland. Amiti, M. - Smarzynska Javorcik, B. (2005): Trade Costs and Location of Foreign Firms in China. IMF Working Paper, WP/05/55.

Bureau van Dijk (2018): Amadeus. https://www.bvdinfo.com/en-us/our-products/company-information/ international-products/amadeus (accessed 08 12, 2018).

Carr, D. L. - Markusen, J. R. - Maskus, K. E. (1998): Estimating the Knowledge-Capital Model of the Multinational Enterprise. NBER Working Paper, No. 6773.

Castellani, D. - Meliciani, V. - Mirra, L. (2013): The Determinants of Inward Foreign Direct Investment in Business Services Across European Regions. Paper Prepared for the ERSA 2013 Congress, Palermo. 
Caughlin, C. C. - Terza, J. V. - Arromdee, V. (1991): State Characteristics and the Location of Foreign Direct Investment within the United States. Review of Economics and Statistics, 73(4): 1-23.

Cieślik, A. (2013): Determinants of the Location of Foreign Firms in Polish Regions: Does Firm Size Matter? Tijdschrift voor Economische en Sociale Geografie, 104(2): 175-193.

den Hertog, P. (2000): Knowledge-Intensive Business Services as Co-Producers of Innovation. International Journal of Innovation Management, 4(4): 491-528.

Falk, M. (2012): Factors Influencing the FDI Location Choice for Knowledge Intensive Services and Heaquarters within the EU and Austria. FIW Research Reports, 2012/13, 2.

Greene, W. (2008): Functional Forms for the Negative Binomial Model for Count Data. Economics Letters, 99(3): 585-590.

Head, C. K. - Ries, J. C. -Swenson, D. L. (1999): Attracting Foreign Manufacturing: Investment Promotion and Agglomeration. Regional Science and Urban Economics, 29(2): 197-218.

Hungarian Investment and Promotion Agency (HIPA) (2017): Shared Services Centres in Hungary.

Kam, W. P. - Singh, A. (2004): The Pattern of Innovation in the Knowledge-Intensive Business Services. Singapore Management Review, 26(1): 21-44.

Kersan-Škabić, I. - Tijanić, L. (2014): Regional Determinants of Foreign Direct Investment in Croatia. Transilvanian Review of Administrative Sciences, Special Issue: 70-89.

Klimek, A. (2018): Agglomeration Economies and Foreign Direct Investment in Advanced Business Services in Poland. International Journal of Management and Economics, 54(1): 69-79.

Lengyel, B. - Szakálné Kanó, I. (2014): Regional Economic Growth in Hungary 1998-2005. What does Really Matter in Clusters. Acta Oeconomica, 64(3): 257-285.

Li, J. - Guisinger, S. (1992): The Globalization of Service Multinationals in the "Triad" Regions: Japan, Western Europe and North America. Journal of International Business Studies, 23(4): 675-696.

Liu, R. - Feils, D. J. - Scholnik, B. (2011): Why are Different Services Outsourced to Different Countries? Journal of International Business Studies, 42(4): 558-571.

Markusen, J. R. (2005): Modeling the Offshoring of White-Collar Services: From Comparative Advantage to the New Theories of Trade and FDI. National Bureau of Economic Research Working Paper, No. 11827.

Markusen, J. R. - Strand, B. (2009): Adapting the Knowledge-Capital Model of the Multinational Enterprise to Trade and Investment in Business Services. The World Economy, 32(1): 6-29.

Micek, G. (2015): FDI Trends in the Business Services Sector: The Case of Poland. In: Galgóczi, B. Drahokoupil, J. - Bernaciak, M. (eds): Foreign Investment in Eastern and Southern Europe after 2008. Still a Lever of Growth? Brussels: ETUI. pp. 297-318.

Miles, I. - Kastrinos, N. - Bilderbeek, R. - den Hertog, P. - Flanagan, K. - Huntink, W. - Bouman, M. (1995): Knowledge-Intensive Business Services: Their Role as Users, Carriers and Sources of Innovation. Report to the EC DG XIII, Luxembourg: Sprint EIMS Programme.

Navaretti, G. B. - Vanables, A. J. (2004): Multinational Firms in the World Economy. Princeton-Oxford: Princeton University Press.

Nefussi, B. - Schwellnus, C. (2010): Does FDI in Manufacturing Cause FDI in Business Service? Canadian Journal of Economics/Revue canadienne d'Economique, 43(1): 180-203.

Pylak, K. - Wojnicka-Sycz, E. - Sycz, P. (2020): What Determines the Success of Economic Transition? Constructing Regional Advantage for Eastern and Western European Regions. Acta Oeconomica, 70(2): 163-194.

Ramasamy, B. - Yeung, M. (2007): The Determinants of Foreign Direct Investment in Services. The World Economy, 33(4): 573-593. 
SARIO (2017): Shared Service \& Business Process Outsourcing Centers in Slovakia. Bratislava: Slovak Investment and Trade Development Agency.

Sass, M. (2011): The Impact of Foreign Direct Investment in Business Services on the Local Economy. The Case of Hungary. In: Rugraff, E. - Hansen, M. W. (eds): Multinational Corporations and Local Firms in Emerging Economies. Amsterdam: Amsterdam University Press. pp. 51-73.

Venables, A. J. (1996): Equilibrium Locations of Vertically Linked Industries. International Economic Review, 37(2): 341-359.

Walsh, J. P. - Yu, J. (2010): Determinants of Foreign Direct Investment: A Sectoral and Institutional Approach. IMF Working Paper, No. WP/10/187.

Wei, Y. - Liu, X. - Parker, D. - Vaydia, K. (1999): The Regional Distribution of Foreign Direct Investment in China. Regional Studies, 33(9): 857-867.

Wirzt, J. - Tuzovic, S. - Ehret, M. (2015): Global Business Services: Increasing Specialization and Integration of the World Economy as Drivers of Economic Growth. Journal of Service Management, 26(4): 565-587.

Yin, F. - Ye, M. - Xu, L. (2014): Location Determinants of Foreign Direct Investment in Services: Evidence from Chinese Provincial-Level Data. Asia Research Centre Working Paper, No. 64.

\section{APPENDIX}

Summary statistics

\begin{tabular}{|l|c|c|c|c|c|}
\hline Variable & Observations & Mean & Std. Dev. & Min & Max \\
\hline Region & \multicolumn{5}{|l|}{} \\
\hline ABS firms & 156 & 12.29 & 29.36 & 1 & 226 \\
\hline Unemployment & 156 & 7.58 & 3.75 & 2.03 & 21.67 \\
\hline Human capital & 156 & 31.01 & 10.67 & 9.36 & 58.46 \\
\hline Number of students & 129 & 88.85 & 86.23 & 2.01 & 580.60 \\
\hline Salaries & 147 & 16.60 & 7.94 & 2.85 & 34.27 \\
\hline GDP & 156 & 59.26 & 65.94 & 4.20 & 587.91 \\
\hline GDP growth & 93 & 1.88 & 1.61 & -1.83 & 7.51 \\
\hline Country & & & & & \\
\hline ABS firms & 198 & 8.44 & 9.30 & 0 & 63 \\
\hline Salaries & 198 & $39,259.03$ & $20,022.37$ & 12,309 & 79,591 \\
\hline Employment in services & 179 & 66.94 & 7.93 & 53.1 & 84.20 \\
\hline Urbanization & 198 & 73.72 & 12.48 & 49.70 & 97.82 \\
\hline University rate & 163 & 66.44 & 14.52 & 10.33 & 95.54 \\
\hline GDP & 197 & 749.40 & 970.52 & 12.06 & $3,852.56$ \\
\hline GNI per capita & 191 & $33,114.29$ & $10,812.96$ & 12,670 & 67,240 \\
\hline Trade openness & 168 & 31.23377 & 43.39 & 9.46 & 245.69 \\
\hline
\end{tabular}

